\title{
UN desert unit to concentrate on national projects
}

Disillusion with transnational programmes to halt the growth of the world's deserts is causing the United Nations Environment Programme (UNEP) to turn to specific national projects, the new director of UNEP's desert unit said last week.

The director, Jens Høgel, said that the criticisms of Professor Mohamed Kassas (reported in Nature last week, p167) were "a long step ahead" from the original political naïvity of the 1977 United Nations Conference on Desertification (UNCOD), which proposed six giant transnational projects based more on scientific optimism than political reality. Professor Kassas was in fact a major force behind UNCOD.

UNCOD passed the six projects on to UNEP, which then had the task of implementing them. Details of the projects-which include matters such as the management of the massive North East African fossil water aquifer-are still being drawn up, but, says $\mathrm{H} \emptyset g e l$, "it is better to put our eggs in national baskets".

One such plan is for the establishment of new industries in arid zones to attract populations back on to desert margins. These would bring water with them and help to stabilise desert movement. Nine countries-Afghanistan, Algeria, India, Iraq, Mali, Mexico, Peru, Spain and Tanzania-are submitting project proposals to a meeting which will take place in Moscow from 5-8 February. The USSR will provide the necessary funding.

Nevertheless national progress "is still going a bit too slow". And while many rich northern states "have indicated very clearly that they are interested" in supporting UNEP's desert work, no money will be forthcoming from them until specific projects are agreed.

"But there is no reason for despair" says Høgel. It took 30 years from the recognition of the problems of development around the time of the second world war before effective action began

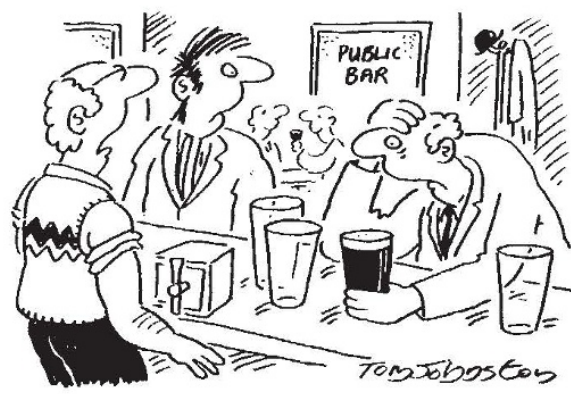

"He drinks one, then needs three more to forget about the cancer in the first." to be possible through the United Nations Development Programme (UNDP) and so on, "We have just recognised desertification (at UNCOD) in October 1977. But it won't take three decades now; we have UNEP, a new will to succeed, and a tremendous pool of international expertise to call on."

Nevertheless there is a great deal of inertia to overcome. The independent Club du Sahel, funded mostly by the US and France, was created in 1975, "but when I left the Sahel four months ago there still wasn't any action".

Høgel is adamant that the UN organisations have not been "sluggish and inefficient" as charged by Professor Kassas. "We are at the top of the scale compared with most bilateral agencies, and what is more you can't lose the United Nation's goodwill.' On the other hand, Høgel can see bilateral agencies imperialistically forcing their solutions onto the recipient countries. "This leads to reticence, the resulting institutions won't function, and it will breed ill will. And the recipient countries hold their best people back".

The approach of UN agencies, like UNEP's desert unit for example, is to encourage the individual countries to create their own projects, "so there is no question of imperialism". Furthermore the UN can call on expertise internationally, whereas bilateral agencies are limited to the donor country.

In the Sahel, however, Høgel recognises the enormous resources that the Club du Sahel can call on-some $\$ 2,000$ million compared with $\$ 60$ million in UNEP's Sahelian office"and the beneficiaries are the same". The Sahelian population is the worst hit and also the poorest desertification area in the world.

The desert unit at UNEP is still very small. UNCOD recommended a professional staff of ten, and some think it should be larger, but so far Høgel has

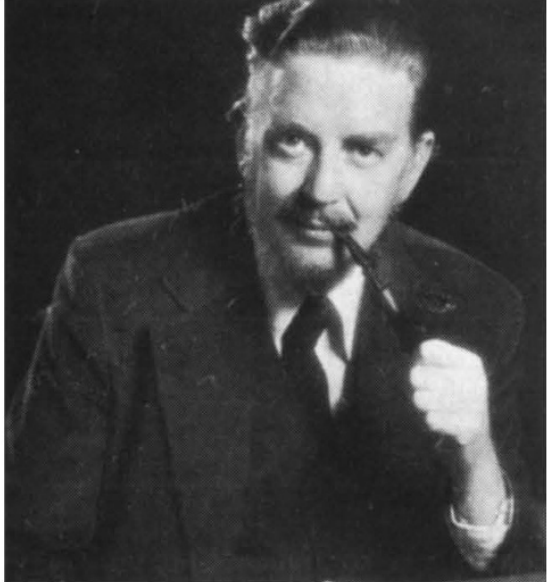

Hogel: supporter of national projects

himself and five others. Previously Høgel was a development manager with UNDP in Upper Volta; he is a 46-yearold Dane with wide experience in the third world. To assist him he has a Soviet professor in soil science, a Sudanese ex-vice-minister of agriculture (and a doctor of veterinary medicine), an Afghani programme officer, and a Belgian meteorologist. The latest recruit is a Malian ex-nomad turned sociologist of nomadic populations.

The unit's work covers the six transnational projects, establishing new national projects, organising national courses on the most basic desert management, and map-making. The original UNCOD map has been widely criticised as impractical, on too small a scale, and lacking clear definitions of the desertification process. A new one at 50 to 100 times the scale (1:1 million) is being drawn up by Professor Harold Dregne at Texas Technical University, but it will take two years and is already leading to a lot of disagreement on defining borders. "But the footwork needed to arrive at the map is very important" says Høgel. "At least we ought to know in detail where the danger regions are."

Robert Walgate

\section{German scientists detect carcinogens in beer}

Scientists at the German Cancer Research Centre in Heidelberg have discovered traces of nitrosamines, one of the strongest known cancer inducing agents, in beers made in Germany, Britain and other European countries.

A two-year study of 158 beers financed by the German government, with support from the US National Cancer Institute, revealed traces of nitrosamines in $70 \%$ of the samples. The chemical, which is thought to be produced by contact with nitrous oxide when the beer's malt is dried, was found in much higher levels than in foodstuffs such as pickled meats, ham and sausage also included in the study.

Dark beers and stronger beers contained higher levels of nitrosamines than light beers such as lager and pilsner, according to the head of the research team, Professor Rudolf Preussman

David Dickson 